\title{
How to Build Risk-based Thinking Methodology Based on Process Approach
}

\author{
Hana Pačaiová * Štefan Markulik, Renata Turisová and Anna Nagyová \\ Technical University of Kosice, Faculty of Mechanical Engineering, Safety and Quality Department, Letna 9, 04200 Kosice, Slovakia
}

\begin{abstract}
The history of management systems is a determined by areas of cultural society development and its needs. Currently, there is probably no organization operating in a global market environment that does not have implemented a specific management system. On one side, that kind system allows transparently to manage all processes and aspects of the organization with the aim of their continual improvement and enter to the market. On the other side, it creates the space for bureaucracy and in some way restricting activities generated by the over-controlled mechanism. The pressure on organizations to continuously increase profits and reduce costs requires the development of such management practices that the interest should not have just a negative impact, for example in the form of loss of the existence or the organization's long-term state in the market. The quality management system was a support system in the development of other systems, through process approach (defined for first time in ISO 9001:2000) created space for the efficient management of preventing losses in the process. This approach had not been accepted or well implemented in practice. Assessment of potential nonconformity in processes, definition of responsibilities and measurement of key parameters had become more formal activity than reliable indicator for management decisions (Spisak et al., 2011). The effort to avoid crisis situations and reach responsible approach to control organizations (from the highest management level to the regional plants) was reflected in the orientation of the risk assessment.
\end{abstract}

Keywords: process; risk; management; decision making; quality.

\section{Introduction}

Risk management became a "glue" between the stones that represents the different management systems in order to build an effective management system based on risk assessment, taking into account the specification of application of each organization (customers, location, activity in the market, resources, etc.).

This paper describes a methodology for implementing the requirements of a quality management system (QMS) based on a "Risk-based Thinking (R-bT)" under the revised of standard ISO 9001:2015. A new approach in the ISO 9001 brings a new perspective where the risk is becoming a fundamental attribute of the whole planning and management processes. The risk is not only perceived as a combination of the probability of occurrence and effect of the negative phenomenon. Article 6.1.1 of the new ISO 9001 defines "desirable and undesirable consequences." This fundamentally changes the view of the conventional perception of risk, which was previously linked only with negative actions (degree of hazard). In other words, it is possible to define the risk in the management process as a positive risk, as a combination of probability and consequences desires, which means the risk levels of opportunity (degree of opportunity). It is important to accept this thinking 
in relation to the ability of the organization to meet legislative requirements, as well as their own in order to enhancement the customer satisfaction. The basis for the establishment the proposed methodology for "Risk-based Thinking management tools" is ISO 31000 and its support titled ISO/IEC 31010 (Risk assessment techniques).

\section{New structure of Management Systems}

As several empirical studies have shown, that implementing QMS may effectively have a positive influence on organization performance (Huarng and Chen, 2002; Kaynak, 2003; Parast et al., 2011). This positive effect may result from their impact on organization costs and differentiation levels.

The implementation of any type of standards is voluntary, although in some sectors it has become an obligatory measure, given the necessary influence of customers (Braun, 2005; Mendel, 2006). Also, research has been done on how far these types of standards have a significant impact on business performance, with some studies finding a positive link (Chow-Chua et al., 2003; Mokhtar and Muda, 2012). However, there are a consensus with a large number of studies which have analyzed the benefits that may be obtained from MS implementation and certification (Link and Naveh, 2006; Zaramdini, 2007; Gavronski et al., 2008).

Management system in today's terms is understood not only as a management methodology, but also as a necessary step to successfully achieving the vision and goals of the organization. Optimally adjusted system allows not only transparently manage processes but helps to reduce the amount of disagreements, minimize costs and ensure efficient production and service provision. It is a common practice that the organization does not control its activities only on one, but often on two or on more systems.

The most common introduced and subsequently Integrated Management Systems (IMS) includes Quality Management System - QMS (ISO 9001), Environmental Management System - EMS (ISO 14001) Occupation Health and Safety Management System - OHSMS (OHSAS 18001), Information Security Management System - ISMS (ISO 27001) and others (Virčíková, et al., 2015).

\subsection{Essential elements of Management systems}

Over the past few decades, the structure of these systems remained largely unchanged, but individual requirements were modified depending on the environment, legislation, interested parties and so on. Despite their different focus, all the systems have a number of characteristic approaches that are identical. These approaches, although they are affected by changing surrounding conditions on them, remained constant and constitute an essential element of all standards and regulations pertaining to quality management systems. These are mainly:

\section{- Process approach \\ - PDCA cycle \\ - Risk Management.}

The one of the essential elements of the management systems is a process approach. According to ISO/TC 176/SC 2/N 544R3 standard, the process approach is a powerful way of organizing and managing activities to create value for the customer and other interested parties. Organizations are often structured into a hierarchy of functional units. Organizations are usually managed vertically, with responsibility for the intended outputs being divided among functional units. The final customer or other interested party is not always visible to all involved. Consequently, problems that occur at the interface boundaries are often given less priority than the short-term objectives of the units. This leads to little or no improvement to the interested party, as actions are usually focused on the functions, rather than on the intended output. The process approach introduces a horizontal management, crossing the barriers between different functional units and unifying their focus to the main objectives of the organization.

The process approach includes establishing the organization's processes to operate as an integrated and completed system (Nenadál, 2016).

The process approach is a part of a methodology that helps the organizations to achieve their objectives through the so-called continuous improvement, ref. as PDCA cycle. The Plan - Do Check-Act (PDCA) cycle can be apply equally to the system as a whole, to individual processes and to operational activities.

Continuous improvement of processes lead to increased revenues (through product reliability) and reduced costs (through process efficiency).

By the effect of globalization, efforts to eliminate 
disagreements, to apply prevention, even another important element got into this group and this is a Risk Management (Rehacek, 2015).

Risks that may impact on objectives and results must be addressed by the management system. In standard ISO 9001:2015 is Risk-based Thinking defined, as something what we all do automatically in everyday life. Risk is commonly understood to have only negative consequences; however, the effects of risk can be either negative or positive. In ISO 9001:2015 risks and opportunities are often cited together. Opportunity is not the positive side of risk. An opportunity is a set of circumstances which makes it possible to do something (e.g. to acquire new customers, to create new product). Taking or not taking an opportunity then presents different levels of risk. Risks that may impact on objectives and results must be addressed by the management system.

$\mathrm{R}-\mathrm{bT}$ is used throughout the process approach in management systems to:

- Decide how risk (positive or negative) is addressed in establishing the processes to improve process outputs and prevent undesirable results.

- Define the extent of process planning and controls needed (based on risk).

-Improve the effectiveness of the management system.
- Maintain and manage a system that inherently addresses risk and meets objectives.

\subsection{Common structure of Management Systems}

All elements of current Management Systems (MSs) have the same requirements regarding to HLS (ISO organization). High level structure for ISO Management Systems Standards is described in the document with the title Annex SL from 2012. It replaces the historical ISO Guide 83 and expands on the base structure already implemented. These standards have common elements; they are described and organized differently, making it difficult for organizations to implement multiple standards. "Annex SL" further addresses these issues by creating a "template" upon which ISO MSS are to be built in the future.

The first standard that in 2013 changed his concept and started taking over perception of requirements relating to the risk was ISO/IEC 27001 Information technology. Security methods. Information security management systems. Requirements. This standard is mainly used to assess the ability of the organization to achieve own safety requirements. As the first one it took over new concept of the standard built on a uniform HLS (see Figure 1) the aims of which is to facilitate the process of integrating several management systems (Zgodavova et. al., 2013).

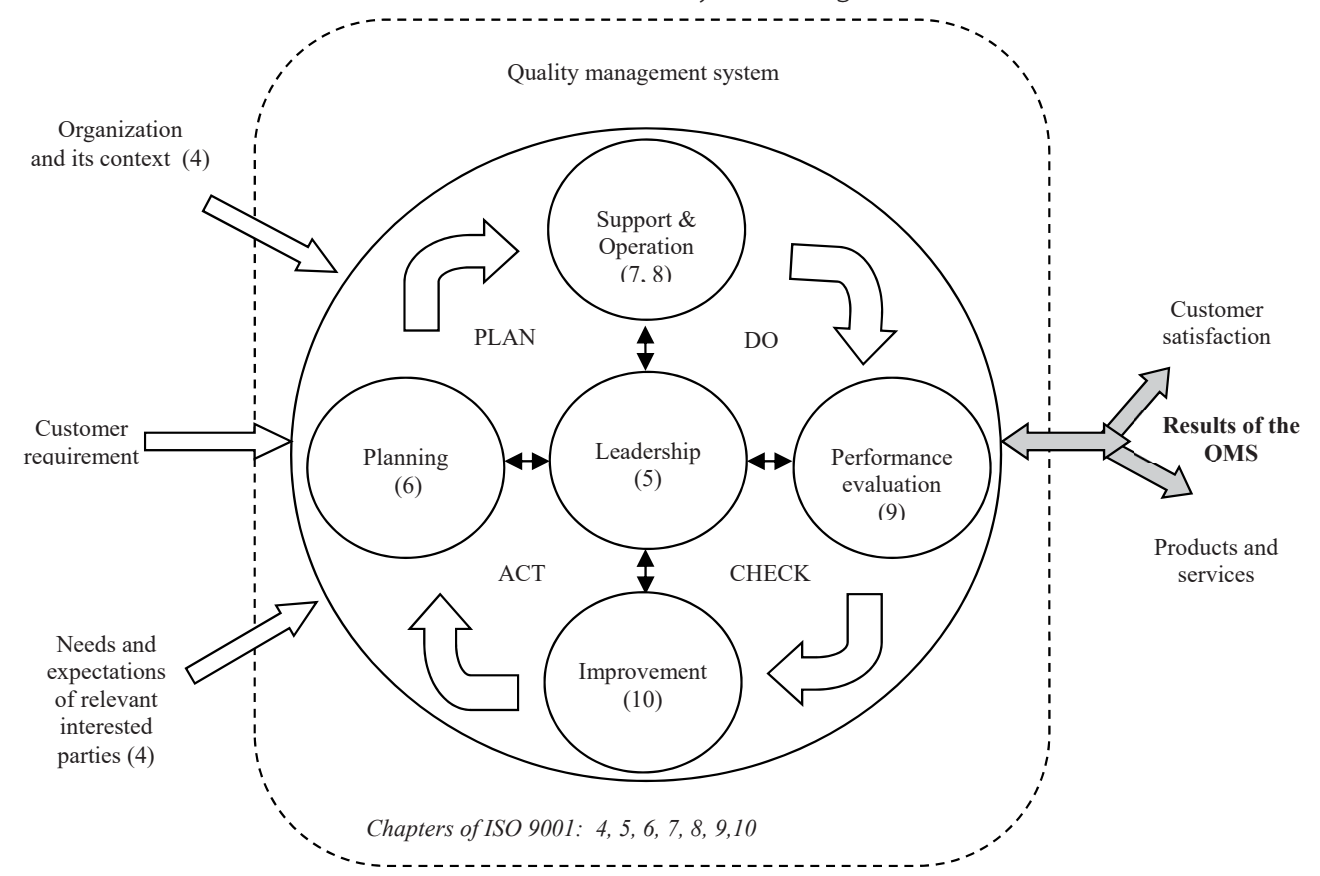

Fig. 1: Model of QMS on the basis of PDCA cycle with HLS structure incorporated. 
Then in 2015 there was a revision of the mentioned ISO 9001 Quality Management Systems. Requirements. This standard obtains probably the biggest change in the structure of its requirements. In addition to changes related terminology, introduces the Context of organization (Chapter 4) as a necessity to perceive requirements of interested parties, planning changes as well as risk assessment (R-bT). ISO 9001:2015 and ISO 31000:2009 are risks, which are perceived not only in a negative way, but also in positive way as opportunities and it is described in more detail in a separate chapter 6.1 Activities for risk and opportunities management.

Similarly as 150 9001, revision process was applied also in other systems e.g. ISO 14001 (ISO 14001:2015) and OHSAS 18001. With regard to the fact that number 18001 is already assigned to another standard, in 2013, the committee of ISO / PC 283 decided that the future standard belonging to OHS Management System will be released under the name ISO 45001. This new standard will be applied to any organization deciding to implement the international OHSMS to reduce or minimize the risk of staff and other participating parties, maintain and continuously improve their health and safety performance and maintain all operations in a line with their stated OSH policies. This draft version of standard prefers elimination of hazard as the best choice to manage the risks of health protection at work (Pacaiova et. al., 2009). In its concept, it states the following: "When preventions and management of measures is determined or changes of existing managements are considered, consideration must be given so as to reduce the risk sub-criteria according to the following hierarchy":

- Risk elimination.

- Replacement of material and equipment by less hazardous materials and processes.

- Engineering Control (Guards and Safeguards).

- Awareness devices.

- Personal protection equipment.

The actual list of standards following HLS is published on the web-site of ISO organization and contains 41 management systems.

\subsection{Risk Management}

Risk management has long been seen as part of economic discipline, focusing on financial management of enterprises. Basically, this systematic process is coming back to the top management level of the organization "packaged" into a holistic understanding of the context and factors potentially affecting successful and sustainable management (Lalonde and Boiral, 2012). Management systems went through a philosophical change (so-called HLS - High Level Structure), which does not change their meaning, but makes problems visible from different perspective.

It is important to understand the systemic character of the real world and an integrated approach to determinate and define management systems (MSs) based on HLS, which are necessary for the ability to effectively solve the problems of the organization (Decision Making).

Systematic problem solving based on R-bT is possible to determinate into 11 steps:

Step 1: Generalizing and defining requirements. Analyses of environmental impacts on business objectives.

Step 2: Clear identification of threats and hazards within the context of the organization.

Step 3: Assess the situation, analyze limitations, lack of process control, risk assessment.

Step 4: Study and understand the interaction between the context of organization and other elements of the system (technology, human, environment, etc.).

Step 5: More detailed analysis of the causes, their interrelationships and their impact on the value of the risk.

Step 6: Evaluate risk management measures.

Step 7: Introduce the proposed solution to interested parties.

Step 8: Evaluate the effectiveness of the presented measures to their impact on risk and opportunities. Step 9: Implementation of the proposed measures. Step 10: Assess the effectiveness and efficiency of implemented measures

Step 11: Monitor and change management (return to Step 1).

\section{Risk-based Thinking modeling}

The proposed methodology for support of R-bT approach is based on basic philosophy (algorithm) of risk assessment and experience achieved within the solution of department research team as a partner of 7RP Integrisk project (http://www. integrisk.eu-vri.eu/). 
Tab. 1: Categorizationof objectives and level of losses (effects).

\begin{tabular}{|c|c|c|c|c|c|}
\hline \multirow{2}{*}{ Objective specification } & \multicolumn{5}{|c|}{ Level of effects } \\
\hline & Negligible & Minor & Moderate & Major & Extreme \\
\hline OH\&S & no impact on human & minor injury & $\begin{array}{l}\text { injury or partial harm } \\
\text { of health }\end{array}$ & $\begin{array}{l}\text { serious injury significant } \\
\text { damage to health }\end{array}$ & $\begin{array}{l}\text { serious injury or death of } \\
\text { several people }\end{array}$ \\
\hline Quality & $\begin{array}{l}\text { product defect has not } \\
\text { impact on the product } \\
\text { quality }\end{array}$ & $\begin{array}{l}\text { product defect must be } \\
\text { additionally removed }\end{array}$ & $\begin{array}{l}\text { occurrence of bigger } \\
\text { amount of errors on the } \\
\text { product }\end{array}$ & $\begin{array}{l}\text { product defect requires } \\
\text { repeated production (satis- } \\
\text { faction of the customer can } \\
\text { be endangered) }\end{array}$ & $\begin{array}{l}\text { product defect requires } \\
\text { the change of design, } \\
\text { risk of losing customer }\end{array}$ \\
\hline Environment & no damage & small leaks & $\begin{array}{l}\text { possible leaks of smaller } \\
\text { extent, measures are a } \\
\text { part of the technology }\end{array}$ & $\begin{array}{l}\text { risk of large leaks, the } \\
\text { effects require higher costs } \\
\text { and time for remedy }\end{array}$ & $\begin{array}{l}\text { serious damage, long- } \\
\text {-term pollution }\end{array}$ \\
\hline Downtime & $\begin{array}{l}\text { no or only small } \\
\text { interruptions }\end{array}$ & $\begin{array}{l}\text { possible short-time } \\
\text { interruption (e.g. for } 1 \\
\text { hours as a maximum) }\end{array}$ & $\begin{array}{l}\text { the repair does not } \\
\text { require more than } 8 \\
\text { hours }\end{array}$ & $\begin{array}{l}\text { possible longer downtime, } \\
\text { recovery requires time up to } \\
24 \text { hours }\end{array}$ & $\begin{array}{l}\text { interruption of operation } \\
\text { requires repair lasting } \\
\text { more than } 24 \text { hours }\end{array}$ \\
\hline Image & $\begin{array}{l}\text { image damage is } \\
\text { unlikely }\end{array}$ & possible single disputes & $\begin{array}{l}\text { Maintenance requires } \\
\text { effort }\end{array}$ & $\begin{array}{l}\text { serious damage to } \\
\text { reputation }\end{array}$ & $\begin{array}{l}\text { the public does not } \\
\text { agree with further } \\
\text { operation of the orga- } \\
\text { nization }\end{array}$ \\
\hline Repair cost & $\begin{array}{l}\text { repair costs are } \\
\text { minimum }\end{array}$ & $\begin{array}{l}\text { repair costs are planned } \\
\text { (budget) }\end{array}$ & $\begin{array}{l}\text { repair costs can exceed } \\
\text { the budget }\end{array}$ & $\begin{array}{l}\text { repair costs seriously } \\
\text { jeopardize the budget }\end{array}$ & $\begin{array}{l}\text { repair costs jeopardize } \\
\text { the existence }\end{array}$ \\
\hline
\end{tabular}

In a company it is important to identify possible areas of losses, which might have influence on given corporate objectives (Pacaiova et al., 2017). We can to specify them, as follows:

\section{- Legal requirements:}

$\checkmark$ Occupation health and safety (OHS).

$\checkmark$ Environmental protection

\section{- Customer requirements:}

$\checkmark$ Production quality.

$\checkmark$ Machinery downtime or reduced production throughput.

\section{- Financial requirements:}

$\checkmark$ Maintenance costs (expensive repair bill).

\section{- Public requirements:}

$\checkmark$ Corporate image (damage to the brand, business impact).

The basic principle for management decision making is to identify the frame and understand the nature of their business through the mentioned area specification (Organization and its context Chap. 4 of ISO structure of Management Systems based on HLS).

Each of these areas can be categorized, for example, into five levels of losses (see Table 1) which combined with the likelihood creates the basis for the Risk Matrix.

Based on established criteria (level of effects) and setting out the categories of probability of nonconformity rise, then the structure of the methodology for assessing the risks jeopardizing the company's objectives described in multi-criteria Risk Matrix - see Table 2.

This second step requires identifying threats or hazards affecting business objectives of organization and estimates the size of the risk.

The procedure of application of this methodology in Table 2 requires the analysis of all identified processes - resulting from mutual systems elements interactions of the (e.g. based on the map of processes) so that each process could be considered from the point of view of the potential effect on objectives of the organization. Criteria for evaluation of processes can be set as follows:

- Critical Process - ref. A: process to which a risk level $\mathrm{H}$ - High (red marked area; the value from 60 to 100) and $\mathrm{S}$ - Serious (yellow - marked area, the value from 30 to 56) can be assigned;

- Middle criticality process - ref. B: process to which risk level M - Middle (green - marked area; value from 10 to 29) risk is assigned;

- Low criticality process - ref. C: process, risk level for the processes $\mathrm{L}$ - Low (blue - marked area; value from 1 to 9 ).

The result is a process risk rate identification process and then the possibility of next step, especially the analysis of the process elements using 
Tab. 2: Multicriterial Risk Matrix (MRM).

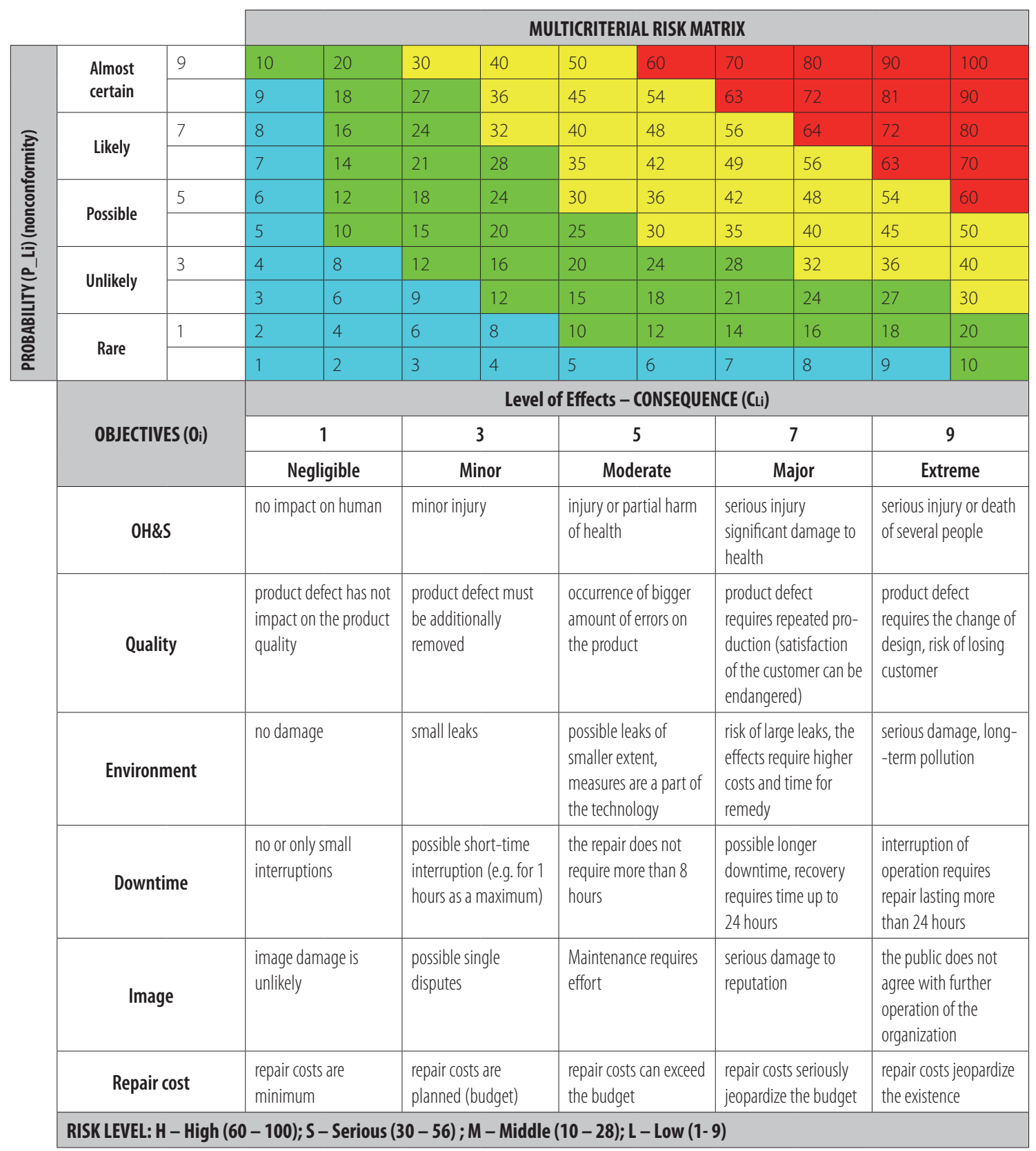

the principle of 4M: M-Man, M-Machine, M-Material, and M-Method.

For the effective risk management, the identification of a critical element in the process (or elements) is very important because it is not the same if from the point of view of risk reduction some measures for improvement of the human activity are taken or if more effective strategy of maintenance to reduce machine failures is required. To ensure that the methodology for the risk of processes assessment, as shown in Table 3, would also consider the elements of the process, it is possible to modify the risk matrix by extension of likelihood by $4 \mathrm{M}$ that requires assignment of other parameters (scales) for the overall assessment. Very similar is possible to define elements and to quantify probability of their influence on the Risk value for external organization threats (e.g. earthquake, terorism, flood, landslide). 
Tab. 3: 4M probability level identification.

\begin{tabular}{|c|c|c|c|c|c|c|c|}
\hline MAN & $L_{M N}$ & METHOD & LMD & MACHINE & LMC & MATERIAL & $L_{M L}$ \\
\hline $\begin{array}{l}\text { deliberate defectiveness } \\
\text { or sabotage }\end{array}$ & +2 & $\begin{array}{l}\text { used methods are inappropriate, } \\
\text { they do not include all use } \\
\text { methods, they do not ensure that } \\
\text { process is under the control }\end{array}$ & +2 & $\begin{array}{l}\text { dangerous areas that threat } \\
\text { unsuitable equipment }\end{array}$ & +2 & $\begin{array}{l}\text { inappropriate material with } \\
\text { possible hidden defects } \\
\text { without any input control }\end{array}$ & +2 \\
\hline $\begin{array}{l}\text { multiple unintentional } \\
\text { defectiveness }\end{array}$ & +1 & $\begin{array}{l}\text { inconsistent methods which } \\
\text { increase that variability of the } \\
\text { process/system }\end{array}$ & +1 & $\begin{array}{l}\text { possible - less dangerous } \\
\text { threat to the operator, necessity } \\
\text { of applying extensive and } \\
\text { expensive corrective actions }\end{array}$ & +1 & $\begin{array}{l}\text { material, which went through } \\
\text { simple input control }\end{array}$ & +1 \\
\hline acceptable defectiveness & 0 & $\begin{array}{c}\text { in the practice, empirically } \\
\text { validated methods, standard } \\
\text { procedures }\end{array}$ & 0 & $\begin{array}{c}\text { safe machinery with standard } \\
\text { defectiveness and acceptable } \\
\text { threat }\end{array}$ & 0 & $\begin{array}{l}\text { appropriate material verified } \\
\text { by adequate statistical control }\end{array}$ & 0 \\
\hline $\begin{array}{l}\text { extremely low } \\
\text { defectiveness }\end{array}$ & -1 & $\begin{array}{l}\text { Sophisticated methods contained } \\
\text { early warning system against } \\
\text { potential defectiveness }\end{array}$ & -1 & $\begin{array}{l}\text { safe machinery with diagnostic } \\
\text { systems to prevent defects and } \\
\text { accidents }\end{array}$ & -1 & $\begin{array}{l}\text { appropriate material, verified } \\
\text { by } 100 \% \text { - automatic checking }\end{array}$ & -1 \\
\hline $\begin{array}{c}\text { almost zero } \\
\text { defectiveness, effective } \\
\text { prevention of mistake }\end{array}$ & -2 & $\begin{array}{l}\text { effective and efficient } \\
\text { system methods capable of } \\
\text { early identification possible } \\
\text { defectiveness, threats, self - } \\
\text { repairing system }\end{array}$ & -2 & $\begin{array}{l}\text { machinery with redundant } \\
\text { systems diagnostics orientated } \\
\text { to system defect prevention }\end{array}$ & -2 & $\begin{array}{l}\text { cooperation with supplier, } \\
\text { long - term satisfaction } \\
\text { with quality ( } 60 \text { quality of } \\
\text { delivery) }\end{array}$ & -2 \\
\hline
\end{tabular}

It's clear, that the proposed methodology requires a structured approach of the elements description of the external and internal environments of the organization, a description of the influences, or causes lead to threat the stated objectives - their hierarchical level. These objectives must be clearly defined and categorized (the specification of consequences and the level of their). From this reason, the process approach as an MSs element must have a specific form and must be describes in the way, that it is possible to clearly define the elements of the system - organization depending on their management (Tkac and Turisova, 2010).

When building the model - 4MMRM (see formula (1)) in the criteria $4 M$, the criteria Man a Method were used for correction of the probability value ( $\mathrm{P}_{\mathrm{Hi}}$. This formula represents possible compensation of wrong people approach with the correct with the applied correct methods and on other way round. Consequence correction $\left(\mathrm{C}_{\mathrm{H}}\right)$ was applied for Machine a Material evaluation. In this case, it is possible apply compensation, where it is possible to expect, that the high quality machines eliminates the lack of poor material and the same, that high quality material is relatively well processed in the less reliable machines. Depending on the organization's management level, this correction for Machine and Material can also be applied for the probability correction (PHi).

This 4MMRM model is possible to mathematically describe as follows:

$$
R_{O i}=P_{H i} \cdot C_{H i},
$$

When:

$$
\begin{gathered}
P_{H i}=\left\{\begin{array}{c}
10, a k P_{L i}+L_{M N}+L_{M D} \geq 10 \\
1, a k P_{L i}+L_{M N}+L_{M D} \leq 1, \\
P_{L i}+L_{M N}+L_{M D} \text { otherwise }
\end{array}\right. \\
C_{H i}=\left\{\begin{array}{c}
10, a k C_{L i}+L_{M C}+L_{M L} \geq 10 \\
1, a k C_{L i}+L_{M C}+L_{M L} \leq 1 \\
C_{L i}+L_{M C}+L_{M L} \text { otherwise }
\end{array},\right.
\end{gathered}
$$

Where

$O_{i}$ - objective, i= $(1,2,3, \ldots n)$;

$C_{L i}$ - attributed value estimating in define scale the level of effect (consequence - Table 2), concerning all impair number from 1 to 9 ,

$P_{L i}-$ attributed value estimating in define scale the level of probability (Table 2), concerning all impair number from 1 to 9 ,

$P_{H i}$ - probabilities correction according 4M criteria, described in Table 3,

$\mathrm{CH}_{\mathrm{H}}$ - measure of consequence (level of effect) corrected by $4 \mathrm{M}$ criteria described in Table 3 .

The level of uncertainty in formula (1) depends on the extent of the described processes, the elements 
of the system and the expression accuracy of their interrelationships.

4MMRM model helps to state useful tool for R-bT application, but also creates the possibility to assess all influences (elements) in organization through hierarchal structure, which have significant effect on their objectives.

\section{Conclusions}

As it is evident from the article, the most recent revisions of management systems complemented by the perception of risk have been continuously running since 2013 . Their aim is to modify the standards in such a way that they would have a similar structure to make them easier to integrate. The content of standards will be unified but specific requirements will be different and the focus on risks and opportunities will be highlighted. In this way the correlation between the management systems will be achieved to ensure effective and efficient manufacture, supply of products and provision of services according to customer requirements. By changes of individual standards, unification of form and approach of management in these standards and by application of a uniform method based on the risk management these uncertainties can be avoided and thus to achieve success in organizations of any nature.

The area of safety has always been perceived differently in various countries, respectively, health protection has been viewed through a socio-cultural prism. However, this fact did not discourage the members of ISO from seeking a common concept of security, which could be defined as a unified international ISO standard. Therefore, the OHSAS 18001 standard has been effective for several years now in the review process to be issued under the name ISO 45001 as a completely new, internationally renowned standard throughout the world. This standard has already had several announced releases; however, it has always been postponed due to the comments and implementation. Each of the country has different legislative support to the safety aspects as well as safety requirements in the manufacturing process. There were also discussions about the staff competences in the team, which prepares the final version of ISO 45001. This was also one of the reasons why the International Standards Organization moved the term of releasing ISO 45001. In the past, there was a draft version for the public, marked as ISO/DIS 45001. The aim of this draft version was to give organizations time to become familiar with the new requirements in advance, and thus prepare them for a smooth transition from the old system to the new occupational health and safety management. Currently, there is a valid public version of ISO 45001, published in March 2018.

Functionality of 4MMRM methodology will be verified to assess the criticality of processes in automotive producers where the process elements are analyzed, using 4M approach.

\section{Acknowledgments}

This contribution is the result of the project implementation APVV-15-0351 "Development and Application of a Risk Management Model in the Setting of Technological Systems in Compliance with Industry 4.0 Strategy" and also KEGA 049TUKE4/2014Designing a Model for E-learning Support of the Education in the Production Quality Bachelor Study Program.

\section{References and Notes}

[1] Braun, B. (2005). Linking Industries Across the World: Processes of Global Networking.Aldershot, London, pp. 3-27.

[2] Chow-Chua, C., Goh, M., \& Wan, T.B. (2003). Does ISO 9000 certification improve business performance? International Journal of Quality \& Reliability Management, 20(8), pp. 936953.

[3] Gavronski, I., Ferrer, G., \&Paiva, E. (2008). ISO 14001 certification in Brazil: motivations and benefits. Journal of Cleaner Production, 16, pp. 87-94

[4] Huarng, F., \& Chen, Y.T. (2002). Relationships of TQM philosophy, methods and performance: a survey in Taiwan. Industrial Management \& Data Systems, 102, pp. 226-234.

[5] Kaynak, H. (2003). The relationship between total quality management practices and their effects on firm performance.Journal of Operations Management, 21, pp. 405435

[6] Lalonde, C., Boiral, O. (2012). Managing risks through ISO 31000: A critical analysis, risk management-journal of risk crisis and disaster, Vol. 14, Issue: 4, pp. 272-300.

[7] Link, S., \&Naveh, E. (2006). Standardization and discretion: does the environmental standard ISO 14001 lead to performance benefits? IEEETransactions on Engineering Management, 53, pp. 508-519.

[8] Mendel, P.J. (2006). The Making and Expansion of International Management Standards: The global Diffusion of ISO 9000 Quality Management Certificates. Oxford University Press, New York.

[9] Mokhtar, M.Z., Muda, M.S., (2012) Comparative Study on Performance Measures and Attributes between ISO and 
Non-ISO Certification Companies. International Journal of Business and Management, Vol 7, pp.185-193.

[10] Nenadal, J. (2016). Quality management systems, What, why and how to measure?Management Press, Praha 2016.

[11] Pacaiova, H., Sinay, J., Glatz, J. (2009). Safety and Risks of Technical Systems, SjF TU v Košiciach, Košice 2009.

[12] Pacaiova, H., Sinay, J., Nagyová, A. (2017).Development of GRAM - A risk measurement tool using risk based thinking principles. Measurement. Vol. 100 (2017), pp. 288-296.

[13] Parast, M.M., Adams, S.G., \& Jones, E.C. (2011). Improving Operational and Business Performance in the Petroleum Industry through Quality Management. International Journal of Quality \& Reliability Management, Vol. 28 Issue: 4, pp. 426-450.

[14] Rehacek, P. (2016). Standards for Risk Management. VISION 2020: Innovation management, development sustainability, and competitive economic growth, 2016, Vols I - VII, pp. 3638-3657.

[15] Singh, P.J. (2008). Empirical assessment of ISO 9000 related management practices and performance relationships. International Journal of Production Economics, 113, pp. 4059.

[16] Spisak, E., Badida, M., Kmec, J., Sobotova, L. (2011).Identification of Structure of Hydro-Erosion Operation. ActaMechanicaSlovaca,Vol. 15, Issue No.2,pp. 80-86.

[17] Tkac, M., Turisova, R. (2010). Statistical processes improvement in praxis. Košice: TU, SjF. $126 \mathrm{p}$.

[18] Zaramdini, W. (2007). An empirical study of the motives and benefits of ISO 9000 certification: the UAE experience. International Journal of Quality \& Reliability Management, 24(5), pp. 472-491.

[19] Zgodavova, K., Petrik, J., Solc, M. (2013). Principles concepts standards of management systemsQuality, metrology, information security.Saarbrücken: LAP LAMBERT Academic Publishing - 2013. 107 p.

[20] Vircikova, E., Solc, M., Girmanova, L. (2015) Management systems and its integration. TU Košice, $160 \mathrm{p}$.

[21] ISO organization, Access available: <http://www.iso.org/ iso/home.html>.

\section{Biographical notes}

prof. Ing. Hana Pacaiova, PhD., (1962) Actual professional or academic position (function and workplace): professor; Where and when he/she graduated: 1987; The most remarkable professional or academic positions or functions till now: professor; Professional orientation or specialization: Occupational Health and Safety, Risk Management, Quality, Maintenance; Membership in the most important professional or academic institutions: Member of Accreditation commission for National Labor Institute (Education), Board Member of Slovak Maintenance Society, Board Member of Slovak Technical diagnostics Society. Technical expert for SNAS; The most relevant publication outputs: 315 outputs. doc Ing. Štefan Markulik, PhD., (1976) Actual professional or academic position (function and workplace): associate professor; Faculty of Mechanical Engineering, Department of safety and quality; Where and when he/she graduated: 2001; The most remarkable professional or academic positions or functions till now: associate professor; Professional orientation or specialization: quality management system, implementation, auditing and application of quality tools for process improvement; The most relevant publication outputs: 99 publications.

doc Ing. RenátaTurisová, PhD., (1975) Actual professional or academic position (function and workplace): associate professor; Faculty of Mechanical Engineering, Department of safety and quality; Where and when he/she graduated: 2014; The most remarkable professional or academic positions or functions till now: associate professor; Professional orientation or specialization: integrated management with focus on quality and safety, statistical and quantitative methods in quality, management and marketing; The most relevant publication outputs: 163 publications.

Ing. Anna Nagyova, PhD., (1979) Actual professional or academic position (function and workplace): lecturer; Where and when he/she graduated: 2003; The most remarkable professional or academic positions or functions till now: lecturer, internal auditor of QMS; Professional orientation or specialization: quality, project management, managements system implementation; The most relevant publication outputs: 77 publications. 


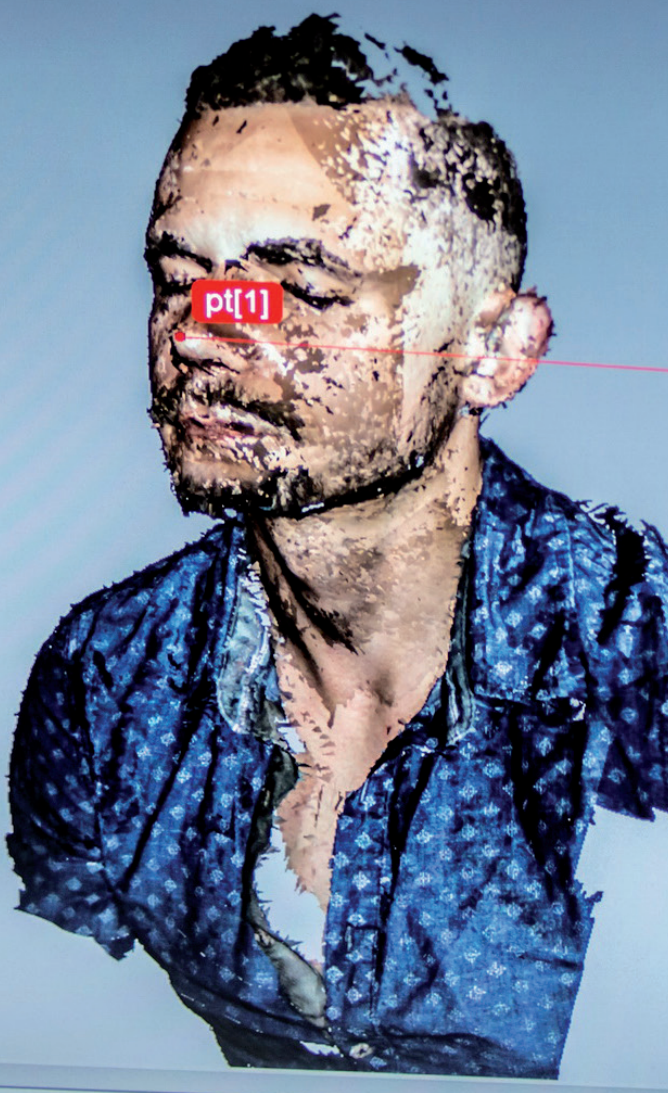

